\title{
THREATENED FISHES OF THE WORLD: Telestes turskyi (Heckel, 1843) (Cyprinidae)
}

\section{Tanja Mihinjač ${ }^{1}$, Zoran Marčić1, Milorad Mrakovčić1, Perica Mustafič ${ }^{1}$, Davor Zanella1, Marko Ćaleta*2}

${ }^{1}$ University of Zagreb, Faculty of Science, Department of Zoology, Rooseveltov trg 6, 10000 Zagreb, Croatia

${ }^{2}$ University of Zagreb, Faculty of Teacher Education, Savska cesta 77, 10000 Zagreb, Croatia

* Corresponding author, E-mail: marko.caleta@ufzg.hr

\begin{tabular}{|c|c|}
\hline ARTICLE INFO & ABSTRACT \\
\hline $\begin{array}{l}\text { Received: } 1 \text { June } 2014 \\
\text { Received in revised form: } 26 \text { June } 2014 \\
\text { Accepted: } 5 \text { July } 2014 \\
\text { Avaible online: } 27 \text { August } 2014 \\
\text { Keywords: } \\
\text { Telestes turskyi } \\
\text { Cyprinidae } \\
\text { Adriatic watershed } \\
\text { Conservation }\end{array}$ & $\begin{array}{l}\text { Tursky dace, Telestes turskyi, is a freshwater species endemic to the } \\
\text { Adriatic drainage. This species is found only in two rivers in Croatia, } \\
\text { the River Krka and River Čikola, and is protected by Croatian law. Major } \\
\text { threats for this species are extremely limited distribution, river regulation, } \\
\text { water extraction and pollution. Suggested conservation actions for } \\
\text { this species are: habitat protection, bans on regulation and alteration } \\
\text { of watercourse and restriction of introduction of alien fish species. }\end{array}$ \\
\hline
\end{tabular}

\section{SYNONYM}

Leuciscus turskyi (Heckel, 1843); Squalius turskyi Heckel, 1843

\section{COMMON NAMES}

Turski klen (Cro); Tursky dace, Čikola riffle dace (Eng)

\section{CONSERVATION STATUS}

IUCN Red list: critically endangered (Crivelli, 2006)

Croatia: critically endangered (Mrakovčić et al., 2006)

\section{IDENTIFICATION}

DIII7-8; All18; VII7; PI14-16; 71 - 79 total lateral line scales. Pharyngeal teeth $2.5-5.2$, gill rakers $8-9$, depth of caudal peduncle $2.0-2.2$ times its length. Dorsal fin starts just posterior to the body midpoint (Fig 1). In preserved individuals there is conspicuous black medilateral stripe. Maximum size is up to $250 \mathrm{~mm}$ TL but usually individuals are up to $160 \mathrm{~mm}$ TL (Seeley, 1886; Vuković and Ivanović, 1971; Mrakovčić, 2006; Kottelat and Freyhof, 2007).

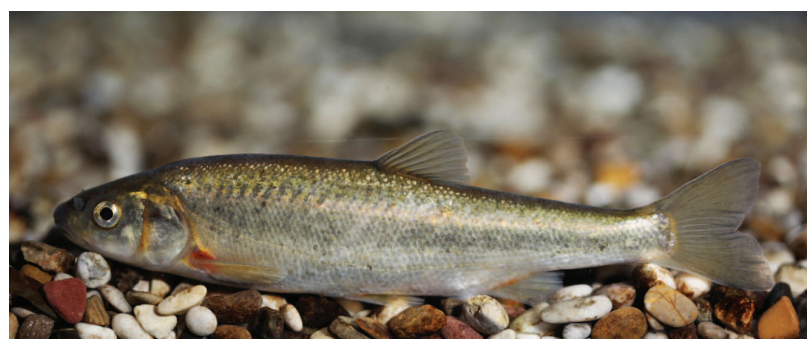

Fig 1. Telestes turskyi $180 \mathrm{~mm}$ TL (photo by Perica Mustafić, May 2011)

\section{DISTRIBUTION}

Endemic to the Adriatic drainage. This species has extremely limited distribution and is found only in two rivers in Croatia, the River Čikola and River Krka. Telestes turskyi has extant of occurrence $<100 \mathrm{~km}^{2}$ and area of occupancy $<10 \mathrm{~km}^{2}$ (Mrakovčić et al., 2006; Crivelli, 2006, Kottelat and Freyhof, 2007).

\section{ABUNDANCE}

According to Vuković and Ivanović (1971), this species was formerly abundant in the River Čikola. In recent years, popu- 
lation has been seriously reduced (Crivelli, 2006; Mrakovčić et al., 2006). Until 2002, Telestes turskyi was listed as extinct (Crivelli, 2006).

\section{HABITAT AND ECOLOGY}

Telestes turskyi inhabits shallow, still and slow flowing waters. This species lives in schools which possibly enter subterranean waters during winter or droughts (Mrakovčić et al., 2006; Kottelat and Freyhof, 2007). It feeds on water invertebrates (Mrakovčić et al., 2006). There is little or no data on the ecology of this species.

\section{REPRODUCTION}

No data.

\section{THREATS}

Telestes turskyi is threatened by its extremely limited distribution (River Krka drainage), river regulation, water extraction and pollution (Crivelli, 2006; Mrakovčić et al., 2006).

\section{CONSERVATION ACTION}

This species is protected in Croatia. It is listed in Appendix III of the Bern Convention.

\section{CONSERVATION RECOMMENDATIONS}

Habitat protection (establishment of ichthyological reserve on the River Krka), bans on regulation and alteration of watercourse, restriction of introductions and control of alien fish species.

\section{REMARKS}

According to some authors, Telestes turskyi was also distributed in Bosnia and Herzegovina in the karstic streams of Livanjsko polje and Lake Buško blato (Vuković and Ivanović, 1971 (as Leuciscus turskyi tenellus); Mikavica, 1988; Maitland, 2000; Mrakovčić et al., 2006). Later, Kottelat and Freyhof (2007) distinguished the species from Bosnia and Herzegovina as Squalius tenellus.

\section{UGROŽENE VRSTE RIBA U SVIJETU: Telestes turskyi (Heckel, 1843) (Cyprinidae)}

\section{Sažetak}

Turski klen, Telestes turskyi, je slatkovodna riba endemična za Jadranski slijev. Živi samo u dvije rijeke u Hrvatskoj, rijeci Krki i rijeci Čikoli te je zakonom zaštićena. Glavni uzroci ugroženosti ove vrste su ograničeno područje rasprostranjenosti, regulacije riječnog toka i onečiščenje vode. Za očuvanje ove vrste predlaže se zaštita staništa te zabrana regulacije i promjene vodotoka kao i zabrana unosa alohtonih vrsta.

Ključne riječi: Telestes turskyi, Cyprinidae, Jadranski slijev, očuvanje

\section{REFERENCES}

Crivelli, A. J. (2006): Telestes turskyi. In: IUCN 2013. IUCN Red List of Threatened Species. Version 2013.2. <www.iucnredlist.org>

Kottelat, M., Freyhof, J. (2007): Handbook of European Freshwater Fishes. Cornol: Kottelat i Berlin: Freyhof, 423 pp.

Maitland, P. S. (2000): Guide to freshwater fish of Britain and Europe. Octopus Publishing Group Limited, London, 256 pp.

Mikavica, D. (1988): Characteristics of the population of Turskyi dace fish (Leuciscus turskyi) (Heckel, 1843) from Lake Buško. Ribarstvo Jugoslavije, 43, 2-7.

Mrakovčić, M., Brigić, A., Buj, I., Ćaleta, M., Mustafić, P., Zanella, D. (2006): Red Book of Freshwater Fish of Croatia. Ministry of Culture, State Institute for Nature Protection, Republic of Croatia, 253 pp.

Seeley, H.G. (1886): The freshwater fishes of Europe. Cassell \& Company, London, Paris, New York and Melbourne, $444 \mathrm{pp}$.

Vuković, T., Ivanović, B. (1971): Freshwater Fishes of Yugoslavia. Zemaljski muzej BiH, Sarajevo, 130 pp. 